\section{New mutation in the CASR gene in a family with familial hypocalciuric hypercalcemia (FHH) and neonatal severe hyperparathyroidism (NSHPT)}

\author{
Nova mutação no gene CASR em uma família \\ com hipercalcemia hipocalciúrica familiar (HHF) e \\ hiperparatireoidismo neonatal grave (HPTNG)
}

Luiza Souza Rodrigues', Ana Carolina Arias Cáu²,

Luciane Zgoda Bussmann', Gabriela Bastida'2, Oscar H. Brunetto',

Pedro Henrique Silveira Corrêa ${ }^{3}$, Regina Matsunaga Martin ${ }^{3}$

\section{SUMMARY}

A loss of calcium-sensing receptor (CASR) function due to inactivating mutations can cause familial hypocalciuric hypercalcemia (FHH) or neonatal severe hyperparathyroidism (NSHPT). NSHPT represents the most severe expression of FHH and courses as a life-threatening condition. The aim of this study was to identify and characterize a CASR mutation in a female infant brought to the health service due to dehydration, apathy, lack of breast feeding and severe hypercalcemia. Molecular analysis was performed on genomic DNA of the index case and her parents. A novel homozygous mutation (p.E519X) in CASR was identified in the proband; both mother and father had the same mutation in heterozygous state, confirming their $\mathrm{FHH}$ condition. The mutation results in a truncated and inactive protein due to the lack of transmembrane and intracellular domains. The identification of this novel CASR gene mutation established the basis of hypercalcemia in this family and allowed a genetic counseling. Arq Bras Endocrinol Metab. 2011;55(1):67-71

\section{SUMÁRIO}

Mutações inativadoras no gene do sensor do cálcio (CASR) podem causar hipercalcemia hipocalciúrica familiar (HHF) ou hiperparatireoidismo neonatal grave (HPTNSG). A HPTNS representa a forma mais grave da HHF cursando com risco de vida. $\mathrm{O}$ objetivo deste estudo foi identificar e caracterizar uma mutação no gene $C A S R$ de uma criança do sexo feminino levada ao hospital em decorrência de desidratação, apatia, dificuldade para mamar e hipercalcemia grave. A análise molecular foi realizada a partir do DNA genômico do caso índice e de seus pais. Uma nova mutação em homozigose (p.E519X) foi identificada no caso índice; ambos, mãe e pai, apresentaram a mesma mutação em heterozigose, o que os caracteriza como portadores de HHF. Essa alteração resulta em uma proteína truncada e inativa devido à falta dos domínios transmembrana e intracelular. A identificação dessa nova mutação estabeleceu a causa da hipercalcemia na família e permitiu o aconselhamento genético. Arq Bras Endocrinol Metab. 2011;55(1):67-71
1 Laboratory of Molecular Genetics and Hormones (LIM/42), Division of Endocrinology, Hospital das Clínicas, Faculdade de Medicina, Universidade de São Paulo (HCFMUSP), São Paulo, SP, Brazil ${ }^{2}$ Hospital de Niños Pedro de Elizalde, Argentina ${ }^{3}$ Diseases Unit Osteometabolic, Division of Endocrinology, HCFMUSP, São Paulo, SP, Brazil

Correspondence to: Regina Matsunaga Martin Av. Dr. Eneas de Carvalho Aguiar, 155, PAMB, $2^{\circ}$ andar, Bloco 6 05403-900 - São Paulo, SP, Brazil reginamm@usp.br

Received on Jul/31/2010 Accepted on Jan/19/2011

\section{INTRODUCTION}

$\mathrm{T}$ he calcium sensing receptor (CASR) is a G-protein coupled receptor well expressed in parathyroid and renal tubule cells that plays an essential role in calcium homeostasis. About 200 mutations have previously been described in the CASR gene which result in loss or gain of function. The most common are missense mutations. Familial hypocalciuric hypercalcemia $(\mathrm{FHH})$ and neonatal severe hyperparathyroidism (NSHPT) can be associated with loss of CASR function. The first condition is an autosomal dominant disease characterized by mild elevations of serum calcium concentration, 
lower urinary calcium, excretion and inappropriately normal PTH levels. Individuals with FHH are usually asymptomatic and the disorder is considered benign. NSHPT represents the most severe expression of FHH and courses as a life-threatening condition with severe hypercalcemia, hypotonia, bone demineralization, fractures, and respiratory distress. Parathyroidectomy is essential for treatment $(1,2)$.

\section{CASE REPORT}

A 36-day-old female infant was brought to the health care service with dehydration, apathy, and lack of breast feeding. She presented severe hypercalcemia, hypophosphatemia, high levels of PTH with normal renal function (Table 1). Chest X-ray showed a narrowed, bell-shaped rib cage (Figure 1). The baby underwent subtotal parathyroidectomy because she remained hipercalcemic despite of hydratation, furosemide and biphosphonate administration. At that moment, the diagnosis of NSHPT was suspected.

After two months, the infant returned to the Hospital de Niños Pedro de Elizalde presenting hypercalcemia recurrence and a skin lesion which rapidly evaluated to sepsis. She was transferred to the intensive care unit where she received appropriate antibiotics and three doses of pamidronate to control hypercalcemia until a total parathyroidectomy was possible (Table 1 and Figure 2).

The second surgery occurred when the patient was 7 months of age and although the goal was to permamnently correct hypercalcemia, her follow-up lab tests showed mild elevated serum calcium concentrations and inappropriately normal PTH levels, probably due to an extra numbered or remained parathyroid (Table 1).
Nowadays, the child is 6 years old, $101 \mathrm{~cm}$ tall (SD -2.17), has normal bone age and she weighs 15.3 $\mathrm{kg}$ (SD -2.06). For the last 3 years to date, her diet has been hypocalcemic (around $500 \mathrm{mg}$ of calcium per day) and supplemented by $800 \mathrm{U} / \mathrm{d}$ of vitamin D. There was no sign of nephrocalcinosis at renal ultrasonography, neither was there any episode of bone fracture.

Her parents are healthy, asymptomatic for the disease, denied medication intake, consanguinity or any similar case in the family. Almost all of their lab tests were normal, although measurement was done only once (Table 2).

In order to confirm in the baby NSHPT disease caused by a CASR loss-of-function, its coding region was analyzed from her genomic DNA. The parents' genomic DNAs were also studied with the aim of knowing if the child's genetic condition was inherited or not.

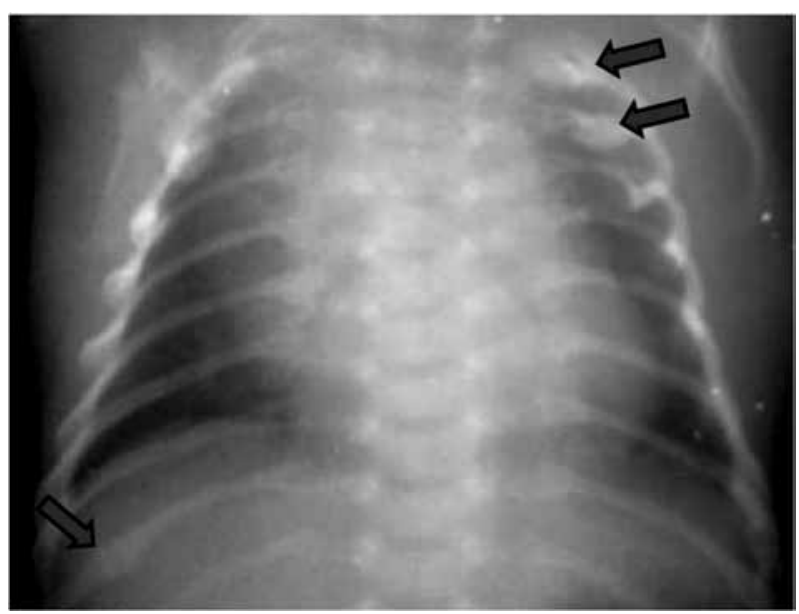

Figure 1. Chest $X$-ray of the child showing a narrowed, bell-shaped rib cage; the top arrows indicate a probable healing of the rib fractures and the bottom one a callusing right rib fracture.

Table 1. Lab evaluation of the index case

\begin{tabular}{|c|c|c|c|c|c|c|}
\hline CA & - & 36 days & 2 months & 4 months & 7 months & $2-6$ yrs \\
\hline Condition & Normal range & $1^{\text {st }}$ admission & $\begin{array}{c}2 \text { weeks after } \\
1^{\text {st }} \text { surgery }\end{array}$ & $\begin{array}{l}2 \text { m after } \\
1^{\text {st }} \text { surgery }\end{array}$ & $\begin{array}{c}1 \text { week after "total" } \\
\text { PTx }\end{array}$ & After PTx \\
\hline $\mathrm{Ca}(\mathrm{mg} / \mathrm{dL})$ & $8.8-10.8$ & 18.1 & 8.0 & 19.2 & 10.6 & $11.1-12.4$ \\
\hline Ca i (mg/dL) & $4.8-5.5$ & 10.6 & - & - & - & 6.1 \\
\hline$P(m g / d L)$ & $\begin{array}{l}5.0-10.8(<1 y r) \\
3.4-6.2(1-12 y r)\end{array}$ & 4.1 & 3.9 & - & 5.3 & $3.8-5.4$ \\
\hline PTH (pg/mL) & $11-62$ & 1036 & 56 & 281 & 27 & $36-50$ \\
\hline $\mathrm{Cr}(\mathrm{mg} / \mathrm{dL})$ & $0.2-0.4(<1 \mathrm{yr})$ & 0.35 & - & - & - & $0.3-0.7$ \\
\hline
\end{tabular}

CA: chronological age; PTx: parathyroidectomy; Ca: total serum calcium; Ca i: ionized serum calcium; P: serum phosphate; Cr: serum creatinine. 
A

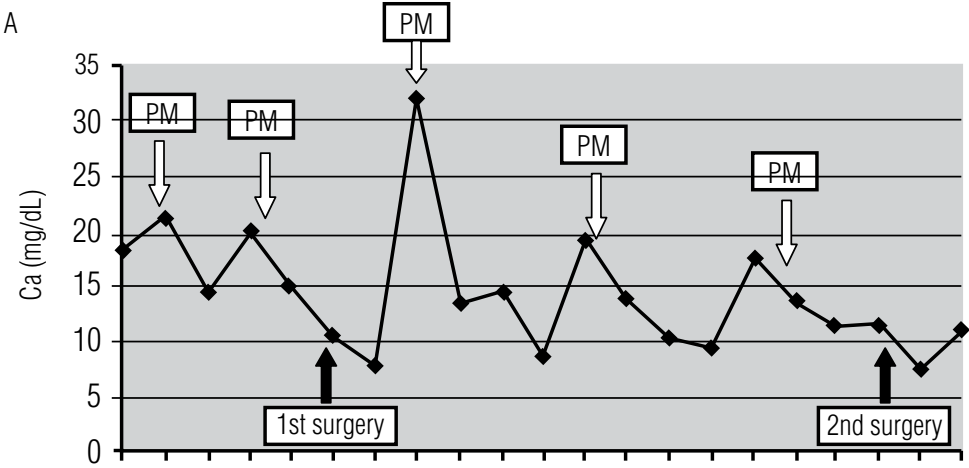

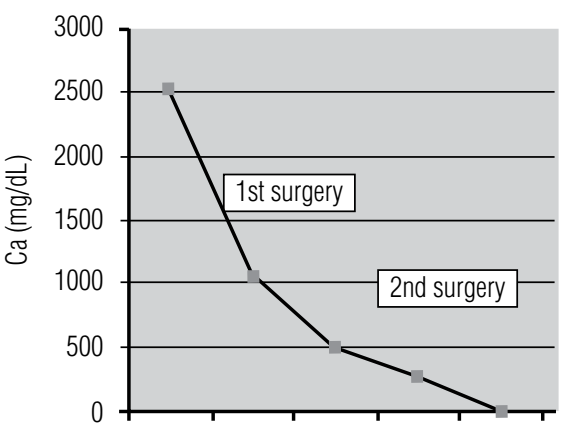

Figure 2. Lab evaluation of serum calcium (A) and PTH levels (B) of the index case. PM: pamidronate.

Table 2. Lab data of the patient's parents

\begin{tabular}{lccc}
\hline Analyte & Normal range & Father & Mother \\
\hline $\mathrm{Ca}(\mathrm{mg} / \mathrm{dL})$ & $8.6-10.2$ & 9.9 & 9.4 \\
$\mathrm{Ca} \mathrm{i}(\mathrm{mg} / \mathrm{dL})$ & $4.7-5.3$ & - & - \\
$\mathrm{P}(\mathrm{mg} / \mathrm{dL})$ & $2.3-4.6$ & 3.8 & 3.3 \\
$\mathrm{PTH}(\mathrm{pg} / \mathrm{mL})$ & $11-62$ & 53.1 & 83.7 \\
$\mathrm{Cr}(\mathrm{mg} / \mathrm{dL})$ & $0.5-0.9($ women$)$ & 0.8 & 0.6 \\
& $0.7-1.2($ men) & & \\
$\mathrm{Cl} \mathrm{Ca} / \mathrm{Cr}$ (urine 24 h) & - & 0.014 & 0.02 \\
$25 \mathrm{OH}-\mathrm{D}$ (ng/mL) & $>30$ & 25.1 & 5.0 \\
\hline
\end{tabular}

Ca: total serum calcium; Ca i: ionized serum calcium; P: serum phosphate; Cr: serum creatinine; $\mathrm{CI} \mathrm{Ca} / \mathrm{Cr}$ : $24 \mathrm{~h}$ urinary calcium to creatinine clearance ratio (the cut-off value differentiating $\mathrm{FHH}$ from primary hyperparathyroidism is 0.01 ); $25 \mathrm{OH}-\mathrm{D}: 25$ hydroxy-vitamin D.

\section{METHODS AND RESULTS}

The study protocol was approved by the Ethics Committee, and informed consent was obtained from the parents. Genomic DNA was extracted from peripheral blood leukocytes from the patient and her parents. Ten intronic primer pairs were used to amplify exons $2-7$ from the CASR gene, which encode the CASR protein. After amplification confirmation by electrophoresis in agarosis gel, PCR products were submitted to automatic sequencing reaction. A homozygous mutation (p.E519X) was identified at exon 5 of CASR in the DNA of the index case. Both mother and father had the same mutation in heterozygous state (Figures 3 and 4 ).

\section{DISCUSSION AND CONCLUSIONS}

Although NSHPT is a rare disease the survival of children depends on early diagnosis and appropriate treatment, usually involving parathyroidectomy (3). In this case, it was decided to perform a subtotal parathyroidectomy because the family belongs to a native Indian community located far from a any health care service and hypocalcemia after total parathyroidectomy could be more deleterious than mild hypercalcemia. However, follow-up of this case showed quick relapse with severe clinical repercussions and a second surgery was necessary to control hypercalcemia.

The molecular basis of NSHPT is a lack of CASR function that can be inherited (in this situation, it was expected that the parents were $\mathrm{FHH}$ ) or secondary to de novo mutation.

FHH is characterized by a persistent, non-progressive mild to moderate hypercalcemia, relative hypocalciuria, and absence of classical clinical features of primary hyperparathyroidism (PHTP). Besides the suspected diagnosis after routine biochemical screening showing high blood calcium levels, another hint of FHH is the persistence or recurrence of hypercalcemia after surgical treatment of PHPT in members of the same kindred (4). It is a benign condition in which the patients may have nonspecific symptoms such as fatigue, weakness, painful joints, and headache.

In this case, even though the child's parents had normal levels of total calcium we do not know the values of ionized calcium neither the values of calcium albumin-adjusted. Moreover there was only one measurement for each individual.

Generally, PTH levels in FHH are not suppressed by hypercalcemia and are inappropriately normal. In a family studied by Zajickova and cols. it was demonstrated that the vitamin D deficiency of proband, determined high levels of PTH which were normalized after vitamin $\mathrm{D}$ repletion (5). In this family, at first glance, the mother's PTH suggests secondary hyperparathyroidism but, as she has $\mathrm{FHH}$, probably her vitamin D replacement should result in hypercalcemia with PTH in the upper limit. In other words, her normocalcemia could be underestimated by vitamin $\mathrm{D}$ deficiency. 

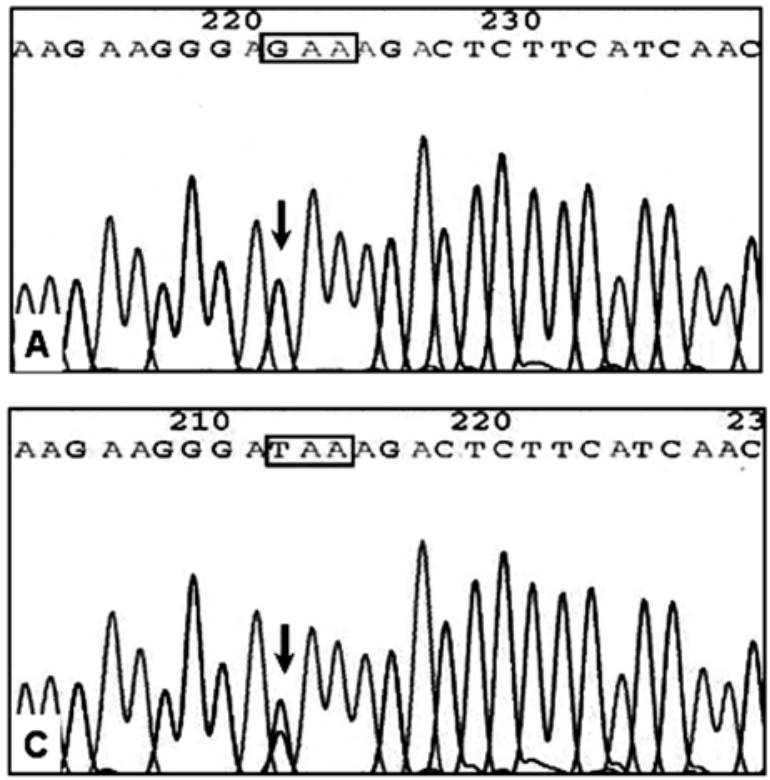
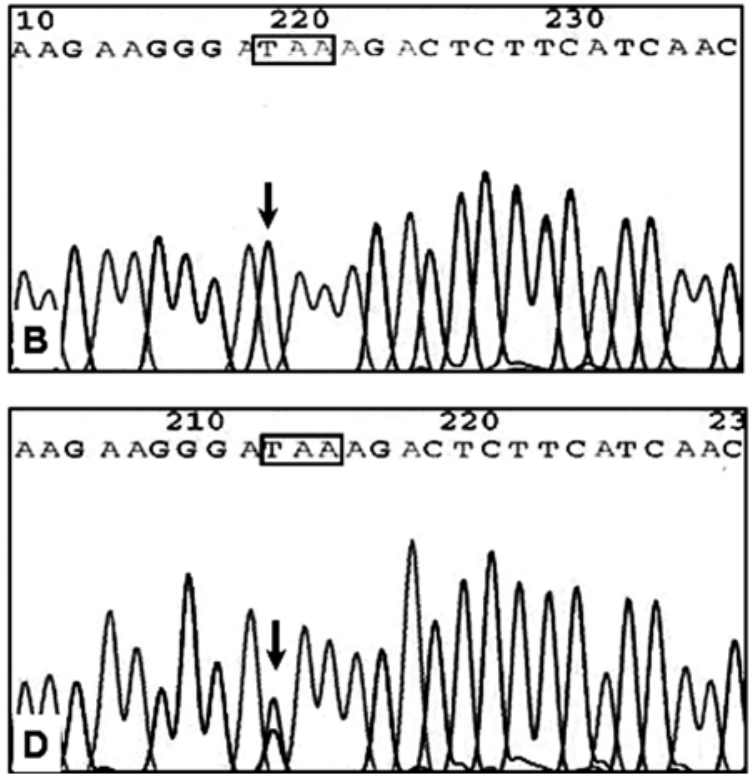

Figure 3. Electropherogram of CASR exon 5 fragment; the arrow points to nucleotide 1993 and the box shows the codon 519. (A) Wild type sample. (B) Proband: substitution $\mathrm{G} \rightarrow \mathrm{T}$ in homozigous state. (C) Proband's father: substitution $\mathrm{G} \rightarrow \mathrm{T}$ in heterozigous state. (D) Proband's mother: substitution $\mathrm{G} \rightarrow$ $\mathrm{T}$ in heterozigous state.

To assess relative hypocalciuria, the ratio of renal calcium clearance to creatinine clearance $(\mathrm{Cl} \mathrm{Ca} / \mathrm{Cr})$ is determined classically. In hypercalcemic cases, this clearance ratio in $\mathrm{FHH}$ averages one third of that found in typical PHPT and a cut-off value $<0.01$ is helpful for diagnosis. This index was based on meta-analysis showing a sensitivity of $81 \%$ for diagnosing $\mathrm{FHH}$, with a specificity of $88 \%$ for excluding PHPT (4). Our patient's parents disclosed normal ratios of $\mathrm{Cl} \mathrm{Ca} / \mathrm{Cr}$ (Table 2). Thus, based exclusively on their lab data, hardly a FHH hypothesis could be considered.
The presence of p.E519X mutation in the CASR of the infant patient, in homozygous state, justifies the NSHPT phenotype. The same mutation in her parents' DNAs, in heterozygous, revealed the diagnosis of FHH and surprisingly confirmed its inherited origin. Even if the parents denied consanguinity, the fact of belonging to a restricted community in Argentina's southwestern (Mapuche tribe) suggests blood relationship.

When the study was being carried out the couple had another child who died in early infancy after presenting similar symptoms of the index case, probably in consequen-
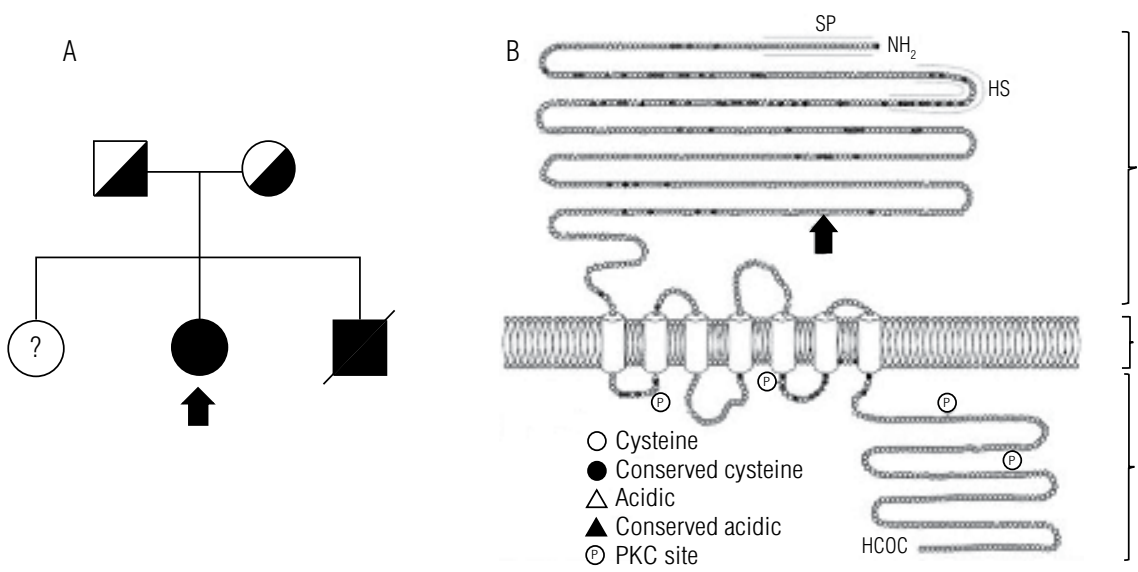

Extracellular domain (612 aa)

Transmembrane domain (250 aa)

Intracellular domain (216 aa)

Figure 4. (A) Pedigree of the family. CASR molecular analysis of the sister and the brother of the proband was not performed. (B) CASR protein showing its extracellular, transmembrane and intracellular domains; the arrow points to the 519 amin oacid adapted from Rodriguez and cols. (6). 
ce of hypercalcemia. On the other hand, calcium metabolism of the sister child was only performed recently and no abnormalities were found; her $\mathrm{Cl} \mathrm{Ca} / \mathrm{Cr}$ ratio is 0.06 (Figure 3). Although late, the results of this research enable genetic counseling for future cases of NSHPT or FHH.

The p.E519X mutation in the CASR has not been previously described and although it has not been done an in vitro study we believe it is the cause of NSHPT phenotype in our patient and of the FHH in her parents because the substitution of guanine by thymine at nucleotide 1993 of the CASR gene predicts a stop codon at 519 aa resulting in a truncated and inactive protein as consequence of loss of the full transmembrane and intracellular domains (Figure 4).

Disclosure: no potential conflict of interest relevant to this article was reported.

\section{REFERENCES}

1. Thakker RV. Diseases associated with the extracellular calcium-sensing receptor. Cell Calcium. 2004;35(3):275-82.

2. D'Souza-Li L. The calcium-sensing receptor and related diseases. Arq Bras Endocrinol Metabol. 2006;50(4):628-39.

3. Waller S, Kurzawinski T, Spitz L, Thakker R, Cranston T, Pearce S, et al. Neonatal severe hyperparathyroidism: genotype/phenotype correlation and the use of pamidronate as rescue therapy. Eur $\mathrm{J}$ Pediatr. 2004;163(10):589-94.

4. Gunn IR, Gaffney D. Clinical and laboratory features of calcium-sensing receptor disorders: a systematic review. Ann Clin Biochem. 2004;41(Pt 6):441-58.

5. Zajickova K, Vrbikova J, Canaff L, Pawelek PD, Goltzman D, Hendy $\mathrm{GN}$. Identification and functional characterization of a novel mutation in the calcium-sensing receptor gene in familial hypocalciuric hypercalcemia: modulation of clinical severity by vitamin $D$ status. J Clin Endocrinol Metab. 2007;92(7):2616-23.

6. Rodriguez M, Nemeth E, Martin D. The calcium-sensing receptor: a key factor in the pathogenesis of secondary hyperparathyroidism. Am J Physiol Renal Physiol. 2005;288(2):F253-64. 